\title{
Comparative Efficiency of Different Organic Acids Spraying in Groundnut on Available Nutrient Status of Calcareous Soils
}

\author{
I. Jagga Rao*, P. Ravindra Babu, P.R.K. Prasad and N. Venkata Lakshmi \\ Department of Soil Science and Agricultural Chemistry, Agricultural College, \\ Bapatla-522 101, India \\ *Corresponding author
}

A B S T R A C T

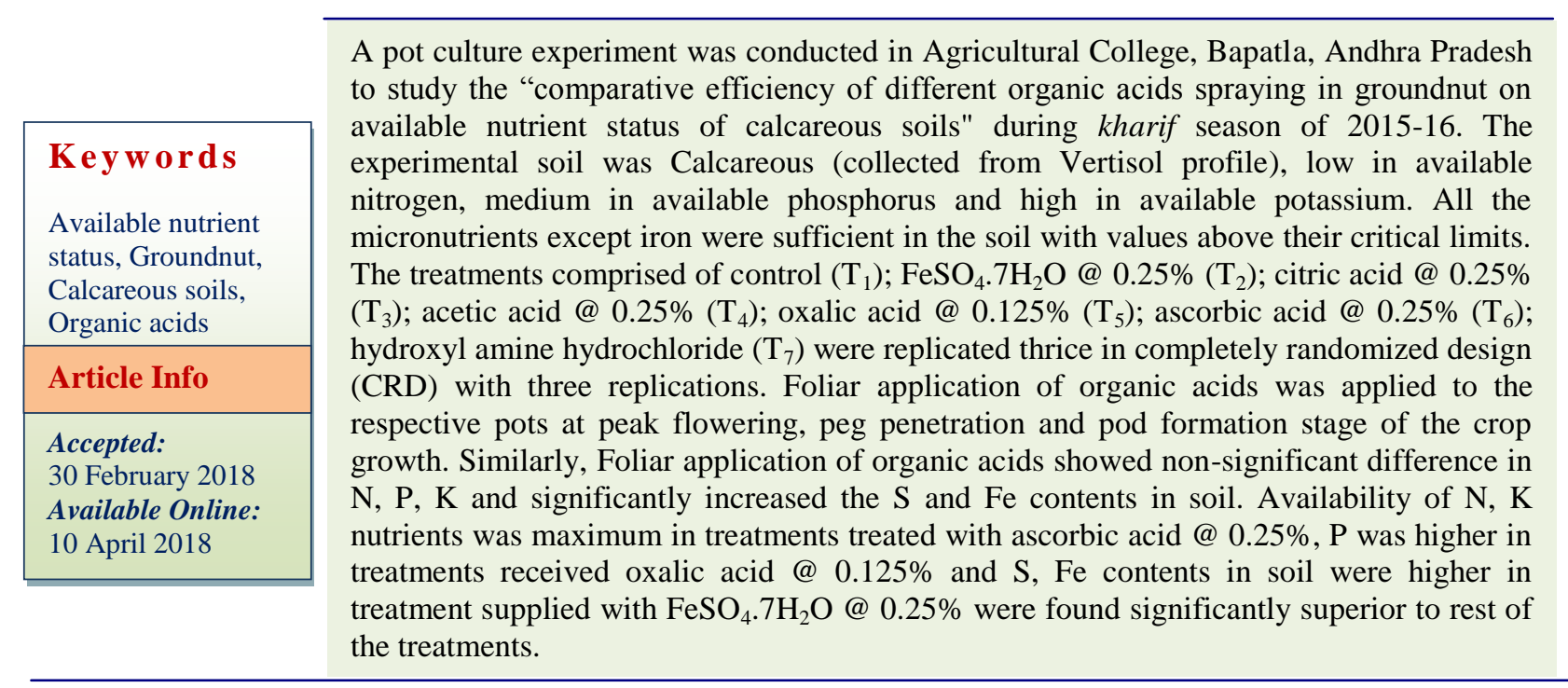

\section{Introduction}

Nutrient management in calcareous soils differ from that in non-calcareous soils because of the effect of soil $\mathrm{pH}$ on soil nutrient availability and chemical reactions that affect the loss or fixation of almost all nutrients. Root exudation of organic acid anions (e.g. citrate, malate, oxalate) is thought to represent one of the main strategies used by plants to enhance nutrient mobilization and acquisition under phosphorus and micronutrient limiting conditions. Organic acids have been shown to induce the dissolution of insoluble ferric oxyhydroxides in soil in the absence of plants, their ability to mobilize iron in a complex rhizosphere environment remains largely unknown. Oxalic acid has the largest ability to chelate many metal ions $\left(\mathrm{K}^{+}, \mathrm{Mn}^{2+}, \mathrm{Zn}^{2+}\right.$, and $\left.\mathrm{Cu}^{2+}\right)$, preventing their precipitation with $\mathrm{P}$. Many studies have also confirmed that oxalic acid can efficiently remove phosphate from $\mathrm{Ca}-\mathrm{P}$ in calcareous soils and from $\mathrm{Fe}-\mathrm{P}$ and Al-P in acidic soils (Jones, 1998; Hinsinger, 
2001). Gerke et al., (2000) also showed that oxalate can be almost as effective as citrate in increasing the solubility of soil P. Iron deficiency is common in soils that have a high $\mathrm{CaCO}_{3}$ due to reduced solubility at alkaline $\mathrm{pH}$ values.

\section{Materials and Methods}

The representative soil samples up to $15 \mathrm{~cm}$ depth were collected during the month of August 2015. The nitrogen was analysed by alkaline potassium permanganate method (Subbiah and Asija, 1956). The phosphorus was analysed by Olsen's method (Watanabe and Olsen, 1965). Potassium in soil was estimated by neutral normal ammonium acetate (Muhr et al., 1965). Available sulphur in soil was extracted with $0.15 \% \mathrm{CaCl}_{2}$ extractant and turbidity was developed with barium chloride followed by measuring intensity of turbidity with spectrophotometer at $420 \mathrm{~nm}$ as outlined by Hesse (1971). Available iron, manganese, zinc and copper in soil was determined by DTPA (Diethylene Triamine Penta Acetic Acid) was used as extractant and AAS was used for estimation as described by Tandon (1998).

\section{Results and Discussion}

\section{Available nutrient status}

Nitrogen content in treatments supplied with foliar application of organic acids treated pots showed non-significant difference among the treatments (Table 1) at all the stages of the crop growth. The data indicated that the higher available nitrogen was observed in ascorbic acid @ $0.25 \%$ treated pots at all stages of the crop growth. However marginal increment in nitrogen content was observed in ascorbic acid @ $0.25 \%$ treatment than to control at all stages of crop growth. The lowest values observed were 183.89, 203.37 and 195.48 (recommended dose of fertilizers only), while the highest values were 206.25, 229.47 and $219.17 \mathrm{~kg} \mathrm{ha}^{-1}$ (ascorbic acid @ 0.25\%) at flowering, peg penetration and harvest stages of crop growth respectively. At flowering, peg penetration stage available nitrogen in soil observed increasing trend, then decreasing trend at harvest stage of crop growth. The increase in the available nitrogen content with the foliar application of organic acids might be due to the mineralization and release of nitrogen.

Phosphorus content in treatments supplied with foliar application of organic acids treated pots showed non-significant trend among the treatments (Table 1) at all the stages of the crop growth. Highest $\left(19.91 \mathrm{~kg} \mathrm{ha}^{-1}\right)$ available Phosphorus $\left(\mathrm{P}_{2} \mathrm{O}_{5}\right)$ at flowering stage was observed in $\mathrm{T}_{5}$ i.e., oxalic acid @ $0.125 \%$ and the lowest $\left(15.38 \mathrm{~kg} \mathrm{ha}^{-1}\right)$ in $\mathrm{T}_{1}$ (recommended dose of fertilizers only). The range was in between $23.72 \mathrm{~kg} \mathrm{ha}^{-1}$ in $\mathrm{T}_{5}$ (oxalic acid @ $0.125 \%)$ and $19.31 \quad \mathrm{~kg} \mathrm{ha}^{-1}$ in $\mathrm{T}_{1}$ (recommended dose of fertilizers only) at peg penetration stage of the crop growth. At harvest the range was in between 22.43 and $18.46 \mathrm{~kg} \mathrm{ha}^{-1}$ in $\mathrm{T}_{1}$ (recommended dose of fertilizers only) treatments, respectively. However increased in the phosphorus content in the organic acids treated pots i.e., $T_{2}$ to $T_{7}$ as compared to control was discernible. Available phosphorus content was increased on foliar application of organic acids might be due to organic acids has been suggested to increase $\mathrm{P}$ availability in calcareous soils (Kpomblekou and Tabatabai 2003), Gerke et al., (2000) showed that oxalate can be almost as effective as citrate in increasing the solubility of soil P. Available potassium $\left(\mathrm{K}_{2} \mathrm{O}\right)$ contents in soil was not significantly influenced by the imposed treatments (Table 1) at all stages of the crop growth. At flowering stage, the highest $\left(540.72 \mathrm{~kg} \mathrm{ha}^{-1}\right)$ value was recorded by $\mathrm{T}_{6}$ (ascorbic acid @ $0.25 \%$ ) followed by $\mathrm{T}_{2}$ i.e., $\mathrm{FeSO}_{4} .7 \mathrm{H}_{2} \mathrm{O} @$ $0.25 \%$ (534.55). 
Table.1 Influence of organic acids on soil available $\mathrm{N}, \mathrm{P}_{2} \mathrm{O}_{5}$ and $\mathrm{K}_{2} \mathrm{O}\left(\mathrm{kg} \mathrm{ha}^{-1}\right)$ at different growth stages of groundnut

\begin{tabular}{|c|c|c|c|c|c|c|c|c|c|}
\hline \multirow[t]{2}{*}{ Treatments } & \multicolumn{3}{|c|}{ Nitrogen } & \multicolumn{3}{|c|}{$\mathbf{P}_{2} \mathrm{O}_{5}$} & \multicolumn{3}{|c|}{$\mathrm{K}_{2} \mathrm{O}$} \\
\hline & Flowering & $\begin{array}{c}\text { Peg } \\
\text { penetration }\end{array}$ & Harvesting & Flowering & $\begin{array}{c}\text { Peg } \\
\text { penetration }\end{array}$ & Harvesting & Flowering & $\begin{array}{c}\text { Peg } \\
\text { penetration }\end{array}$ & Harvesting \\
\hline $\mathrm{T}_{1}$ : Control & 183.89 & 203.37 & 195.48 & 15.38 & 19.31 & 18.46 & 509.64 & 554.16 & 521.59 \\
\hline $\mathrm{T}_{2}: \mathrm{FeSO}_{4} \cdot 7 \mathrm{H}_{2} \mathrm{O} @ 0.25 \%$ & 202.62 & 220.32 & 214.11 & 17.51 & 22.15 & 21.24 & 534.55 & 567.35 & 541.36 \\
\hline $\mathrm{T}_{3}$ : Citric acid @ $0.25 \%$ & 197.66 & 214.25 & 209.35 & 19.58 & 22.73 & 21.69 & 525.97 & 585.54 & 549.04 \\
\hline $\mathrm{T}_{4}$ : Acetic acid @ $0.25 \%$ & 194.79 & 217.27 & 203.29 & 18.68 & 21.95 & 20.70 & 533.51 & 581.34 & 543.27 \\
\hline $\mathrm{T}_{5}:$ Oxalic acid @ $0.125 \%$ & 199.72 & 223.10 & 209.17 & 19.91 & 23.72 & 22.43 & 524.69 & 566.49 & 538.09 \\
\hline $\mathrm{T}_{6}:$ Ascorbic acid @ 0.25\% & 206.25 & 229.47 & 219.17 & 18.92 & 22.61 & 21.58 & 540.72 & 593.04 & 557.34 \\
\hline $\begin{array}{lcc}\mathrm{T}_{7}: & \text { Hydroxyl } & \text { amine } \\
\text { hydrochloride @ } 0.25 \% & \\
\end{array}$ & 191.84 & 212.05 & 198.62 & 18.85 & 21.98 & 20.76 & 529.17 & 574.74 & 539.83 \\
\hline SEm \pm & 6.20 & 7.03 & 6.66 & 0.94 & 1.40 & 0.87 & 17.88 & 19.19 & 18.67 \\
\hline CD@ 0.05 & NS & NS & NS & NS & NS & NS & NS & NS & NS \\
\hline CV $(\%)$ & 5.46 & 5.61 & 5.57 & 6.07 & 6.51 & 5.94 & 5.86 & 5.78 & 5.97 \\
\hline Initial & & 196.0 & & & 14.49 & & & 520.01 & \\
\hline
\end{tabular}

Table.2 Influence of organic acids on available sulphur (ppm) in soil at different growth stages of groundnut

\begin{tabular}{|c|c|c|c|}
\hline Treatments & Flowering & Peg penetration & Harvesting \\
\hline $\mathrm{T}_{1}$ : Control & 33.50 & 34.78 & 33.08 \\
\hline $\mathrm{T}_{2}: \mathrm{FeSO}_{4} .7 \mathrm{H}_{2} \mathrm{O} @ 0.25 \%$ & 39.48 & 41.14 & 40.63 \\
\hline $\mathrm{T}_{3}$ : Citric acid @0.25\% & 39.36 & 40.38 & 40.27 \\
\hline $\mathrm{T}_{4}:$ Acetic acid @ $0.25 \%$ & 38.75 & 39.43 & 38.43 \\
\hline $\mathrm{T}_{5}:$ Oxalic acid @ $0.125 \%$ & 38.45 & 39.51 & 39.11 \\
\hline $\mathrm{T}_{6}$ : Ascorbic acid @ $0.25 \%$ & 38.98 & 39.03 & 38.27 \\
\hline T7: Hydroxyl amine hydrochloride @ $0.25 \%$ & 37.65 & 38.96 & 38.12 \\
\hline SEm \pm & 1.11 & 1.17 & 1.19 \\
\hline CD@ 0.05 & 3.38 & 3.54 & 3.61 \\
\hline CV (\%) & 5.07 & 5.18 & 5.39 \\
\hline Initial & & 34.59 & \\
\hline
\end{tabular}


Table.3 Influence of organic acids on available iron ( $\mathrm{ppm})$ in soil at different growth stages of groundnut

\begin{tabular}{|c|c|c|c|}
\hline Treatments & Flowering & Peg penetration & Harvesting \\
\hline $\mathrm{T}_{1}:$ Control & 2.56 & 2.61 & 2.48 \\
\hline $\mathrm{T}_{2}: \mathrm{FeSO}_{4} .7 \mathrm{H}_{2} \mathrm{O} @ 0.25 \%$ & 3.47 & 3.59 & 3.51 \\
\hline $\mathrm{T}_{3}$ : Citric acid @ $0.25 \%$ & 3.79 & 4.09 & 3.81 \\
\hline $\mathrm{T}_{4}:$ Acetic acid @ $0.25 \%$ & 3.56 & 3.86 & 3.56 \\
\hline $\mathrm{T}_{5}$ : Oxalic acid @ $0.125 \%$ & 3.81 & 4.11 & 3.85 \\
\hline $\mathrm{T}_{6}$ : Ascorbic acid @ 0.25\% & 3.53 & 3.80 & 3.57 \\
\hline T7: Hydroxyl amine hydrochloride @ $0.25 \%$ & 3.76 & 3.83 & 3.79 \\
\hline SEm \pm & 0.10 & 0.11 & 0.10 \\
\hline CD@ 0.05 & 0.30 & 0.33 & 0.30 \\
\hline $\mathrm{CV}(\%)$ & 4.59 & 4.87 & 4.71 \\
\hline Initial & & 2.70 & \\
\hline
\end{tabular}

Table.4 Influence of organic acids on available micronutrients ( $\mathrm{ppm}$ ) in soil at harvest stage of groundnut

\begin{tabular}{|c|c|c|c|c|}
\hline Treatments & Iron & Manganese & Zinc & Copper \\
\hline $\mathrm{T}_{1}:$ Control & 2.48 & 12.11 & 0.95 & 15.29 \\
\hline $\mathrm{T}_{2}: \mathrm{FeSO}_{4} .7 \mathrm{H}_{2} \mathrm{O} @ 0.25 \%$ & 3.51 & 12.36 & 0.97 & 15.73 \\
\hline $\mathrm{T}_{3}$ : Citric acid @ 0.25\% & 3.81 & 12.72 & 1.02 & 19.15 \\
\hline $\mathrm{T}_{4}$ : Acetic acid @ 0.25\% & 3.56 & 12.64 & 1.01 & 17.67 \\
\hline $\mathrm{T}_{5}:$ Oxalic acid @ $0.125 \%$ & 3.85 & 12.87 & 1.05 & 20.10 \\
\hline $\mathrm{T}_{6}$ : Ascorbic acid @ 0.25\% & 3.79 & 12.56 & 0.99 & 17.63 \\
\hline T7: Hydroxyl amine hydrochloride @ $0.25 \%$ & 3.57 & 12.22 & 0.98 & 17.49 \\
\hline SEm \pm & 0.10 & 0.38 & 0.03 & 0.57 \\
\hline CD @ 0.05 & 0.30 & NS & NS & 1.73 \\
\hline $\mathrm{CV}(\%)$ & 4.71 & 5.30 & 5.88 & 5.61 \\
\hline Initial & 2.70 & 12.13 & 0.92 & 4.04 \\
\hline
\end{tabular}


At peg penetration stage of crop growth the highest values (593.04 and $585.54 \mathrm{~kg} \mathrm{ha}^{-1}$ ) were recorded in the treatment received ascorbic acid @ $0.25 \%\left(\mathrm{~T}_{6}\right)$ recorded the highest (593.04) followed by citric acid@ 0.25\% (585.54 kg $\left.\mathrm{ha}^{-1}\right)$. At harvest the highest value $(557.34 \mathrm{~kg}$ $\mathrm{ha}^{-1}$ ) was recorded in ascorbic acid @ $0.25 \%$ $\left(\mathrm{T}_{6}\right)$. The lowest available potassium contents of 509.64, 554.16 and 521.59 at flowering, peg penetration and harvest, respectively were recorded in $\mathrm{T}_{1}$ (control i.e. recommended dose of fertilizers only).

Sulphur content in treatments supplied with foliar application of organic acids treated pots showed significance influence (Table 2) at all the stages of the crop growth. Among the treatments, $\mathrm{FeSO}_{4} .7 \mathrm{H}_{2} \mathrm{O}$ @ $0.25 \%$ recorded higher sulphur content $(39.48,41.14$ and 40.63 ppm). The treatments $\mathrm{FeSO}_{4} .7 \mathrm{H}_{2} \mathrm{O} @ 0.25 \%$, citric acid @ 0.25\% $\left(\mathrm{T}_{3}-39.36,40.38\right.$ and 40.27 ppm), ascorbic acid@0.25\% ( $\mathrm{T}_{6}-38.98,39.03$ and $38.27 \mathrm{ppm})$, acetic acid @ $0.25 \%\left(\mathrm{~T}_{4}\right.$ $38.75,39.43$ and 38.43 ppm), oxalic acid @ $0.125 \%\left(\mathrm{~T}_{5}-38.45,39.51\right.$ and $\left.39.11 \mathrm{ppm}\right)$ and hydroxyl amine hydrochloride $\left(\mathrm{T}_{7}-37.65,38.96\right.$ and $38.12 \mathrm{ppm}$ ) were on par with each other and significantly superior over control (33.50, 34.78 and $33.08 \mathrm{ppm})$.

The data indicated that (Table 3) the higher available iron was observed in all the treatments when compared to control at all stages of the crop growth. Among the treatments, the treatment receiving oxalic acid@0.125\% was recorded highest available iron concentration of $3.81,4.11,3.85 \mathrm{ppm}$ at flowering, peg penetration and harvesting respectively, which was on par with the treatment receiving citric acid@ $0.25 \%$ which recorded available iron concentration of $3.79,4.09,3.81 \mathrm{ppm}$. This may be due to high $\mathrm{CaCO}_{3}(17.5 \%)$ per cent. However, the foliar spray of oxalic acid significantly increased iron, here it was difficult to attribute the reason behind the increase in concentration of iron after spraying of oxalic acid. These were in accordance with findings of Pierre et al., (2002) and Ramireddy and Basavaraj (2012).
Available manganese (Table 4) contents in soil were not significantly influenced by the imposed treatments at harvest stage of crop growth. At harvesting stage, the highest (12.87 ppm) value was recorded by $\mathrm{T}_{3}$ (citric acid @ $0.25 \%$ ) followed by $\mathrm{T}_{6}$ i.e., ascorbic acid @ $0.25 \%(12.72 \mathrm{ppm})$. The lowest available manganese content of 12.11 was recorded in $\mathrm{T}_{1}$ (control). Najafi and Jalali (2015) reported that on foliar application of organic acids, there was no significance influence of soil available manganese content.

The data indicated that (Table 4) the higher (1.05 ppm) available zinc was observed in oxalic acid @ $0.125 \%$ treated pots followed by citric acid@0.25\% (1.02 ppm) and acetic acid (a) $0.25 \%$ (1.01) at harvesting stage of the crop growth. However slight increment in zinc content was discernible in foliar spray treatments than to control (0.95) at harvest stage of crop growth. Available $\mathrm{Zn}$ content was increased on foliar application of organic acids might be due to mineralization process and ability to chelate metal ions $\left(\mathrm{Mn}^{2+}, \mathrm{Zn}^{2+}\right.$, and $\left.\mathrm{Cu}^{2+}\right)$. The results were confirmed with the findings of Jones (1998) and Hinsinger (2001).

The data (Table 4) indicated that the higher available copper was observed in all the treatments when compared to control at harvest stage of the crop growth. Among the treatments, the treatment receiving oxalic acid @ 0.25\% was recorded higher available copper concentration of $20.10 \mathrm{ppm}$ and is on par with the treatment receiving citric acid @ $0.25 \%\left(\mathrm{~T}_{3}\right)$ which recorded available copper concentration of 19.15 ppm followed by acetic acid @ $0.25 \%$ $\left(\mathrm{T}_{4}-17.67 \mathrm{ppm}\right)$, ascorbic acid @ 0.125\% $\left(\mathrm{T}_{6^{-}}\right.$ $17.63 \mathrm{ppm})$ and hydroxyl amine hydrochloride @ $0.25 \%$ ( $\left.\mathrm{T}_{7}-17.49 \mathrm{ppm}\right)$. This might be due to organic acids mainly exist in soil as natural products of root exudates, microbial secretions, and decomposition of plant and animal residues. Due to their chelation and complexion characteristics, organic acids are important products in controlling mobility and transport of metals (Jiang et al., 2012). Najafi and Jalali (2015) reported that Organic acids affected the 
behavior of $\mathrm{Cu}$ in soils. This result can be attributed to higher stability constants of $\mathrm{Cu}$ organic acids complexes.

\section{References}

Gerke, J., Beissner, L and Romer, W. 2000. The quantitative effect of chemical phosphate mobilization by carboxylate anions on $\mathrm{P}$ uptake by a single root. I. The basic concept and determination of soil parameters. Journal of Plant Nutrition and Soil Science. 163. 207-212.

Hinsinger, P. 2001. Bioavailability of soil inorganic $\mathrm{P}$ in the rhizosphere as affected by root-induced chemical changes: A review. Plant and Soil. 237: 173-195.

Jackson, M.L. 1973. Soil chemical analysis, Prentice Hall India Private Limited, New Delhi: 41.

Jiang, H., Li, T., Han, X., Yang, $\times$ and He, Z. 2012. Effects of $\mathrm{pH}$ and low molecular weight organic acids on competitive sorption and desorption of cadmium and lead in paddy soils. Environmental Monitoring and Assessment. 184 (10): 6325-6335.

Jones, D.L. 1998. Organic acids in the rhizosphere- A critical review. Plant and Soil. 205: 25-44.

Kpomblekou, A.K and Tabatabai, M.A. 2003. Effect of low molecular weight organic acids on phosphorus release and phytoavailability of phosphorus in phosphate rocks added to soil. Agriculture, Ecosystems and Environment. 100: 275284.

Muhr, G.R., Datta, N.P., Sankarasubramoney, H., Leley, V.K and Dunabha, R.L. 1965.
Soil testing in India. $2^{\text {nd }}$ ed, USAID Mission to India, New Delhi.

Najafi, S and Jalali, M. 2015. Effects of organic acids on cadmium and copper absorption and desorption by two calcareous soils. Environmental Monitoring Assessment. 187: 585.

Pierre, J. L., Fontecave, M and Crichton, R. R. 2002. Chemistry for an essential biological process; the reduction of ferric iron. BioMetals. 15 (4): 341-346.

Puri. 1930. Standard methods for analysis of soil plant and water analysis, scientific Publishers, New Delhi, India.

Ramireddy, T and Basavaraj, B. 2012. Role of organic acids in amelioration of Iron chlorosis in groundnut (Arachis hypogaea L.) grown on calcareous Vertisol. M.Sc. (Ag) Thesis, University of Agricultural Sciences, Dharwad, India.

Subbiah, B.V and Asija, C.L. 1956. A rapid procedure for the estimation of available nitrogen in soils. Current Science. 25: 259-260.

Watanabe, F.S and Olsen, S.R. 1965. Test for ascorbic acid method for determining phosphorus in water and sodium bicarbonate extracts of soil. Soil Science Society of American Journal. 29: 677678.

Zhou, D. M., Chen, H. M., Wang, S. Q and Zheng, C. R. (2003). Effects of organic acids, o-Phenylenediamine and pyrocatechol on cadmium sorption and desorption in soil. Water, Air and Soil Pollution. 145: 109-121.

\section{How to cite this article:}

Jagga Rao, I., P. Ravindra Babu, P.R.K. Prasad and Venkata Lakshmi, N. 2018. Comparative Efficiency of Different Organic Acids Spraying in Groundnut on Available Nutrient Status of Calcareous Soils. Int.J.Curr.Microbiol.App.Sci. 7(04): 3784-3789.

doi: https://doi.org/10.20546/ijcmas.2018.704.426 